\title{
MEDICINE
}

\section{ДІАГНОСТИЧНА ІНФОРМАТИВНІСТЬ ТА ПРОГНОСТИЧНЕ ЗНАЧЕННЯ КЛІНІКО- АНАМНЕСТИЧНИХ ПОКАЗНИКІВ ДЛЯ ОЦІНЮВАННЯ СЕРЦЕВО-СУДИННОГО РИЗИКУ СЕРЕД ПАЦІЕНТІВ МОЛОДОГО ВІКУ 3 НАДМІРНОЮ МАСОЮ ТІЛА}

Pудь O. M.

Україна, Київ, Національна медична академія післядипломної освіти імені П. Л. Шупика

DOI: https://doi.org/10.31435/rsglobal_sr/31012020/6868

\section{ARTICLE INFO}

Received 16 November 2019 Accepted 13 January 2020 Published 31 January 2020

\begin{abstract}
The article presents the current scientific data and the results of research about the prevalence, informative and prognostic significance of the most common risk factors of cardiovascular diseases in young adults with arterial hypertension, overweight and obesity.
\end{abstract}

\section{KEYWORDS}

arterial hypertension, young age, overweight, risk factors of cardiovascular diseases.

Citation: Рудь О. M. (2020) Diahnostychna Informatyvnist ta Prohnostychne Znachennia KlinikoAnamnestychnykh Pokaznykiv dlia Otsiniuvannia Sertsevo-Sudynnoho Ryzyku Sered Patsiientiv Molodoho Viku z Nadmirnoiu Masoiu Tila. Science Review. 1(28). doi: 10.31435/rsglobal_sr/31012020/6868

Copyright: (C) 2020 Рудь О. М. This is an open-access article distributed under the terms of the Creative Commons Attribution License (CC BY). The use, distribution or reproduction in other forums is permitted, provided the original author(s) or licensor are credited and that the original publication in this journal is cited, in accordance with accepted academic practice. No use, distribution or reproduction is permitted which does not comply with these terms.

Артеріальна гіпертензія (АГ) залишається однією з найбільш актуальних проблем сучасної медицини внаслідок значного поширення та ключової ролі у розвитку багатьох серцево-судинних захворювань (СС3). За даними експертів Всесвітньої організації охорони здоров’я (BОO3) CC3 є основним етіологічним фактором інвалідизації та смертності населення $[1,2]$.

Одним із доведених та модифікованих факторів ризику (ФР) ССЗ, в тому числі АГ вважають надлишок маси тіла. За даними Framingham study збільшення маси тіла на 1 кг спричиняс підвищення АТ на 1 мм рт. ст. [3]. За прогнозами ВООЗ, чисельність населення 3 ожирінням збільшується на $10 \%$ кожного десятиріччя і до 2025 року набмірну вагу матимуть більше $50 \%$ людей усього світу $[4,5]$. Особливу увагу привертає ріст захворюваності на АГ серед молодих людей працездатного віку. За оцінками експертів підвищений АТ є причиною дев'яти мільйонів смертельних випадків щорічно [6]. Цей ризик може значно знизитися при ранній діагностиці та впровадженні відповідних методів профілактики.

Відповідно до рекомендацій Європейського товариства кардіологів (European Society of Cardiology (ESC) та Європейського товариства гіпертензії European Society of Hypertension, ESH (ESC) 3 лікування артеріальної гіпертензії 2018 року, кількісна оцінка серцево-судинного ризику (ССР) є важливою частиною процесу менеджменту пацієнта 3 артеріальною гіпертензією (АГ) [7]. Свропейські настанови 3 профілактики серцево-судинних (СС) захворювань ще з 2003 року рекомендують користуватися системою SCORE для оцінки 10-ти річного коронарного ризику фатальних CC подій. За системою SCORE класифікація CCP 
ризику ділить пацієнтів на осіб з високим, помірним та низьким ССР. Особи із АГ та документованими серцево-судинними захворюваннями (СС3) мають ризик летальних СС подій $>10 \%$ та відносяться до високого ССР. Такі пацієнти автоматично не потребують оцінки ССР, так як це не змінює тактику лікування АГ.

Однак, недоліком системи SCORE є вікове обмеження - можливість її застосовування лише для пацієнтів 3 40-річного віку і старше. Однак, ССР однозначно залежить від віку. Вважається, що серед осіб молодого віку абсолютний ризик СС подій є незмінно низьким, незалежно від наявних додаткових ФР, що спотворює дані про загальний ССР та тактику лікування пацієнта із АГ молодого віку. Для більш ефективного розуміння рівня ризику та правильної тактики лікування було розроблено поняття «вік ССР», який часто для пацієнтів 40річного віку з низьким рівнем абсолютного ризику, відповідає такому особам 60-річного віку.

Тому, ретельний аналіз факторів високого ССР відіграє ключову роль у диференційному виборі тактики лікування пацієнтів молодого віку із АГ І ступеня.

Мета. Оцінити інформативність та прогностичне значення найбільш поширених клініко - анамнестичних, лабораторних та інструментальних факторів ризику серцево-судинних захворювань серед пацієнтів молодого віку з АГ І ступеня та надмірною масою тіла.

Матеріали і методи. Дослідження проведено на кафедрі сімейної медицини НМАПО імені П.Л. Шупика на базі Комунального закладу Київської обласної ради (КЗ КОР) «Київська обласна клінічна лікарня» (КОКЛ) та «Київський обласний кардіологічний диспансер» (КЗ КОР).

Усі методи дослідження проводилися згідно рекомендацій виробників діагностичних тестсистем на основі сучасних принципів лабораторних технологій [8], із дотриманням основних положень Конвенції Ради Свропи про права людини та біомедицини (від 04.04.1997р.), Гельсінської декларації Всесвітньої медичної асоціації про етичні принципи проведення наукових медичних досліджень за участю людини (1964-2004 рр.) [9], та у відповідності до всіх вимог належної клінічної практики (GCP) від 1996 р. [10] і наказу МО3 України №690 від 23.09.2009p. 3 внесеними змінами згідно наказу МОЗ України №639 від 01.10.2015р. Програма та протокол дослідження були розглянуті комісією з етики НМАПО імені П.Л. Шупика (протокол № 1 від 18 січня 2016р.) схвалено, що дане дослідження відповідає сучасним етичним нормам та принципам щодо проведення клінічних досліджень. Всі пацієнти перед включенням у дослідження підписували інформовану згоду на участь в обстеженні та лікуванні.

Всім пацієнтам проводили аналіз найбільш поширених клініко - анамнестичних ФР за допомогою розробленого та опрацьованого опитувальника пацієнта, а також комплекс клініко лабораторних та інструментальних обстежень. Загальне клінічне обстеження включало загально - клінічний огляд, вимірювання АТ та антропометричних показників: маси тіла (кг), зросту (м) з обчисленням індексу маси тіла (IMT) і оцінювання ступеня ожиріння; вимірювання об’єму талії (ОТ) (см) і об’єму стегон (ОС) (см), обчислення співвідношення ОТ/ОС для аналізу типу розподілу жирової тканини.

Лабораторні дослідження включали визначення показників ліпідного та вуглеводного обміну, рівня сечової кислоти, гормонів інсуліну та лептину, молекул судинної адгезії VCAM1, маркерів хронічного запалення: високочутливого С-реактивного протеїну (СРП) та фактору некрозу пухлин- $\alpha$ (TNF- $\alpha)$ в сироватці крові.

Для визначення стану судинної стінки і моніторингу атеросклеротичного ураження всім хворим проводилося дуплексне сканування СА на ультразвуковому апараті "Ultima Pro-30" (“РАДМІР”, Україна) лінійним датчиком з частотою 5-10 МГц. Товщину КІМ оцінювали у зоні його максимального візуального потовщення при орієнтації площини сканування паралельно поздовжній вісі судини. Для визначення функції ендотелію всім хворим проводилося дуплексне сканування брахіальних артерій (БА) лінійним датчиком 3 частотою 5-10 МГц у В-режимі. Визначення ендотелій - залежної вазодилятації (ЕДЗВ) проводили після вимірювання базального діаметру (D) БА до та після тесту з реактивною гіперемією. ЕДЗВ розраховували за формулою:

$$
\% \mathrm{EДЗВ}=\left(\frac{\text { піковий D- базальний } \mathrm{D}}{\text { базальний } \mathrm{D}}\right) * 100
$$

Статистична обробка отриманих результатів проводилася у вигляді таблиць “Microsoft Excel”. Статистичний аналіз здійснювався за допомогою комп’ютерної програми «Statistica 6,0».

Результати дослідження та їх обговорення. Згідно критеріїв включення/виключення в дослідженні брали участь 74 пацієнти молодого віку з АГ І ступеня відповідно до критеріїв Рекомендацій Європейського товариства кардіологів (European Society of Cardiology - ASC) та 
Свропейського товариства гіпертензії (European Society of Hypertension - ASH) з лікування артеріальної гіпертензії 2018 року та наказу МО3 України №384 від 24.05.12p., а також 3 надлишком маси тіла та 3 різними ступенями ожиріння. Середній вік обстежуваних становив $34,55 \pm 0,68$ роки, середня тривалість АГ 7,04 $\pm 0,86$ місяців.

Основним критерієм розподілу пацієнтів на групи для подальшого аналізу клініко анамнестичних ФР був рівень ССР, розрахований за допомогою онлайн - калькулятора за шкалою Heartscore (www.heartscore.org). Для осіб молодше 40 років ССР рекомендовано розраховувати за рівнем систолічного АТ (САТ), загального холестерину (3Х), ліпопротеїнів високої щільності (ЛПВЩ) та статусу тютюнопаління.

При обчисленні СС-ризику за допомогою онлайн-калькулятора розраховувався сумарний ССР за рівнем САТ, 3Х, ЛПВЩ та статусом тютюнопаління, а також СС-ризик за IMT. Таким чином, було сформовано 2 клінічні групи (КГ): КГ-1 - 21 пацієнт (11 чоловіків та 10 жінок) із низьким та помірним ССР та КГ-2, яка включала 53 пацієнти (46 чоловіків та 7 жінок) із помірним та високим ССР. За середнім рівнем показника ССР пацієнти достовірно відрізнялися $(\mathrm{p}<0,05)$ i розподілялися наступним чином: серед пацієнтів КГ-2 5 (9,43\%) пацієнтів мали низький сумарний СС-ризик, 3 них лише 4 (7,55\%) пацієнти при визначення СС-ризику за IMT, 47 пацієнтів (88,68\%) помірний сумарний і $43(81,13 \%)$ - помірний СС-ризик за IMT, 1 (1,88\%) пацієнт мав високий сумарний ризик, а $6(11,23 \%)$ - високий СС-ризик за IMT. У КГ-1 $11(52,38 \%)$ мали низький загальний СС-ризик і $6(28,57 \%)$ з них - низький СС-ризик за IMT, помірний сумарний СС-ризик відмічався серед 10 (47,62\%) пацієнтів. Помірний СС-ризик за IMT відмічався у 15 (71,43\%) пацієнтів КГ-1. Високий СС-ризик у КГ-1 не відмічався.

Таблиця 1. Розподіл пацієнтів за категорією СС-ризику

\begin{tabular}{|c|c|c|}
\hline Показник & $\begin{array}{l}\mathrm{K} \Gamma-2, \\
\mathrm{n}=53\end{array}$ & $\begin{array}{c}\mathrm{K} \Gamma-1, \\
\mathrm{n}=21\end{array}$ \\
\hline $\begin{array}{c}\mathrm{M} \pm \mathrm{m} \\
\text { сумарного СС-ризику }\end{array}$ & $1,78 \pm 0,19^{a}$ & $0,76 \pm 0,21$ \\
\hline $\begin{array}{c}\mathrm{M} \pm \mathrm{m} \\
\mathrm{CC}-\text { ризику за IMT }\end{array}$ & $2,88 \pm 0,28^{a}$ & $1,48 \pm 0,24$ \\
\hline $\begin{array}{l}\text { Низький } \\
\text { сумарний }<1 \%,(\mathrm{n} / \%)\end{array}$ & $5(9,43 \%)$ & $11(52,38 \%)$ \\
\hline $\begin{array}{l}\text { Низький } \\
\text { IMT }<1 \%,(n / \%)\end{array}$ & $4(7,55 \%)$ & $6(28,57 \%)$ \\
\hline $\begin{array}{l}\text { Помірний сумарний СС-ризик } \\
1 \%-5 \%,(\mathrm{n} / \%)\end{array}$ & $47(88,68 \%)$ & $10(47,62 \%)$ \\
\hline $\begin{array}{l}\text { Помірний СС-ризик за IMT } \\
1 \%-5 \%,(\mathrm{n} / \%)\end{array}$ & $43(81,13 \%)$ & $15(71,43 \%)$ \\
\hline $\begin{array}{l}\text { Високий сумарний СС-ризик } \\
>10 \%,(\mathrm{n} / \%)\end{array}$ & $1(1,88 \%)$ & - \\
\hline $\begin{array}{l}\text { Високий СС-ризик за } \\
>10 \%,(\mathrm{n} / \%)\end{array}$ & $6(11,23 \%)$ & - \\
\hline
\end{tabular}

Примітка $1 .{ }^{\mathrm{a}}$ - різниця між групами достовірна, $\mathrm{p}<0,05$

За демографічною характеристикою усі досліджувані розподілялися наступним чином: КГ-1 склали 21 пацієнт: 10 (47,62\%) жінок та 11 (52,38\%) чоловіків. Середній вік обстежених

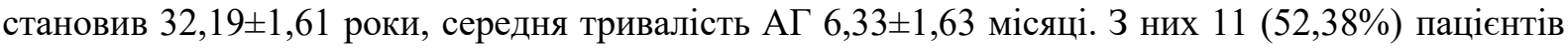
мали надлишок маси тіла, $6(28,57 \%)$ - ожиріння I ступеня, 2 (9,52\%) пацієнти - ожиріння II ступеня і 2 (9,52\%) - ожиріння III ступеня.

КГ-2 складали 53 пацієнти: 46 (86,8\%) чоловіків і 7 (13,2\%) жінок, середній вік яких становив $35,5 \pm 0,89$, середня тривалість АГ 7,32 0,6 місяці. В усіх пацієнтів КГ-2 відмічався розподіл жирової тканини за центральним типом (абдомінальним). За класифікаціє надмірної маси тіла серед обстежених КГ-2 у 20 (37,7\%) пацієнтів відмічався надлишок маси тіла, у 16 (30,18\%) ожиріння I ступеня, у 18 (33,96\%) пацієнтів відмічалося ожиріння II ступеня і у $1(1,88 \%)$ ожиріння III ступеня. Особливістю КГ-2 є переважання осіб чоловічої статі, що підтверджує дані статистичних результатів: серед населення України у кожного шостого чоловіка віком від 25-ти до 34-х років виявляється підвищення АТ, у віковій групі 35-44 роки - у кожного третього, а у 45-54 роки - у кожного другого чоловіку. Тоді як серед осіб жіночої статі у віковій групі 25-34 роки 
підвищення АТ фіксується у кожної двадцятої жінки, але в подальшому поширеність АГ аналогічна такій серед осіб чоловічої статі [11].

Для стратифікації ССР нами було оцінено наявність найбільш поширених клінікоанамнестичних ФР СС3, а саме: недотримання здорового харчування, обмеження фізичної активності, тютюнопаління, стан хронічного стресу, та сімейний анамнез передчасних СС3 (у віці $<55$ років для чоловіків та $<60$ років для жінок). 3'ясовано що, недотримання здорового харчування, а саме раціон із підвищеним вмістом кухонної солі та тваринних жирів, є найбільш поширеним етіологічним фактором підвищеного ССР. Відмічено також, що даний фактор достовірно частіше (на рівні $\mathrm{p}<0,05)$ зустрічається серед осіб чоловічої статі обох клінічних груп $(100,0 \%$ серед чоловіків і $(50,0 \pm 15,8) \%$ - серед жінок КГ- 1 відповідно, та $(91,3 \pm 4,2) \%$ серед осіб чоловічої статі та $(28,6 \pm 17,1) \%$ - серед осіб жіночої статі у КГ-2). Частота інших ФР детально представлено на Рис. 1.

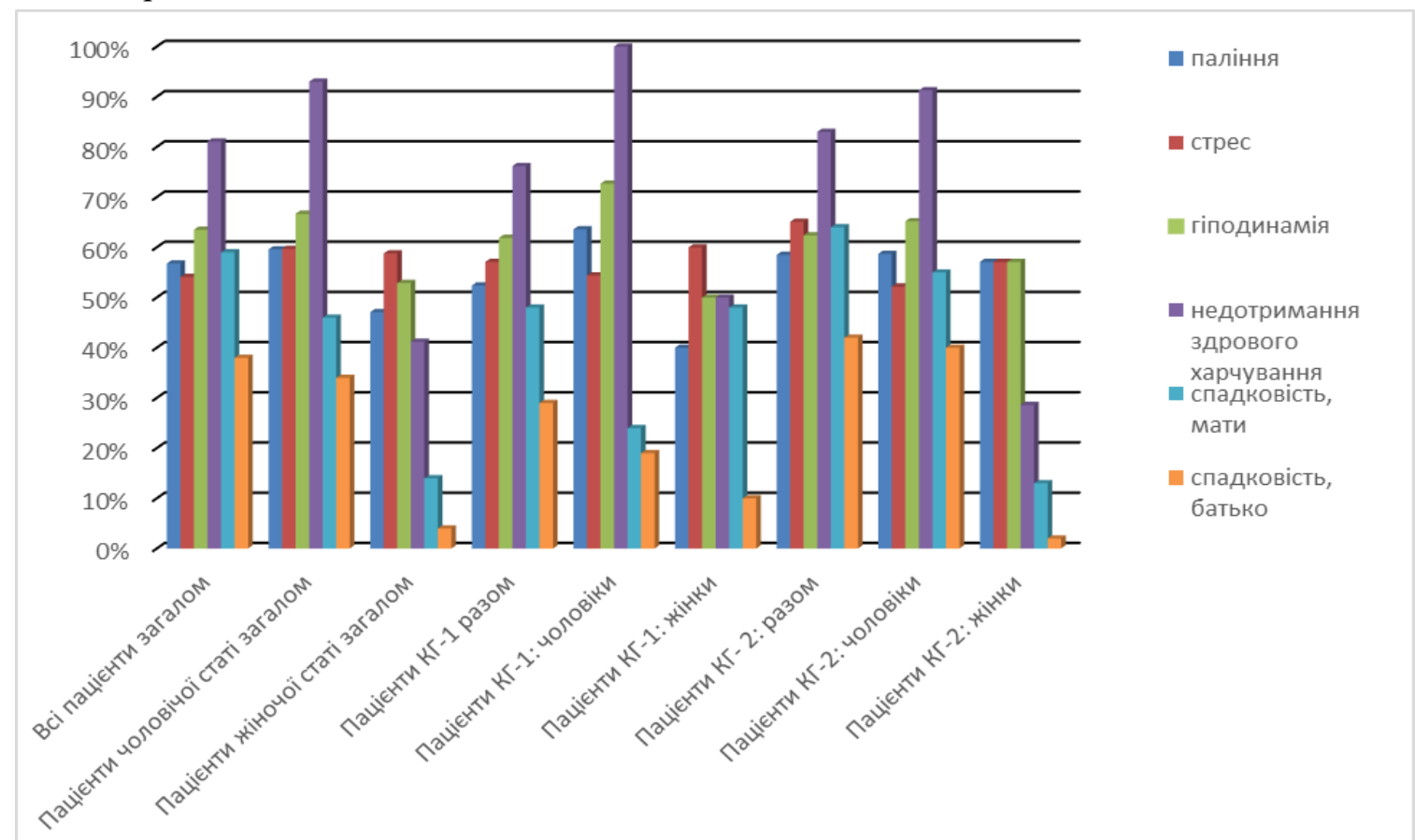

Рис.1. Частота окремих клініко-анамнестичних факторів серцево-судинного ризику серед пацієнтів з АГ-1 та надмірною масою тіла.

Дослідження діагностичної цінності та прогностичного значення клінікоанамнестичних ФР СС3 у пацієнтів молодого віку з АГ І ступеня та надмірною масою тіла проводили шляхом їх порівняння серед клінічних груп. Визначення критеріїв прогнозування базувалася на використанні технології послідовного аналізу Вальда у модифікації Е.В. Гублера $[12,13]$ для розрахунку діагностичної цінності (вимірювалася в одиницях інформативності бітах) кожного фактору та їх прогностичне значення, представленого у вигляді прогностичних коефіцієнтів (ПК, пат). Додатково визначали силу впливу кожного з аналізованих факторів ( $\eta^{2}$, \%) та розраховували достовірність відмінностей у його частоті у порівнянні з КГ-1.

У якості діагностичних критеріїв високого ризику СС3 нами досліджено ряд анамнестичних, конституційно-біологічних, лабораторних та інструментальних показників, та 3'ясовано, що 7 критеріїв мають достовірну значимість та високу інформативність (при I > 0,700 біт). Ранговий розподіл достовірних та високоінформативних факторів серед обстежуваних представлено у табл.2.

Найвищу діагностичну цінність ( $\mathrm{I}=2,739$ біт) та силу впливу $\left(\mathrm{\eta}^{2}=23,0 \%\right)$ становила наявність такого ФР, як обтяжений спадковий анамнез за ранніми ССЗ. Даний фактор достовірно частіше зустрічався серед осіб КГ-2 з помірним та високим ССР у порівнянні з КГ-1 - 3 низьким ССР $((71,7 \pm 6,2) \%$ та $(47,6 \pm 10,9) \%$ відповідно з спадковим анамнезом по одному з батьків), а також $((26,4 \pm 6,1) \%$ та $(14,3 \pm 7,6) \%$ відповідно з обтяженим анамнезом обох батьків). На другому ранговому місці - лабораторний показник порушення обміну ліпідів - підвищення рівня $3 \mathrm{X}>5,0$ ммоль/л. Серед пацієнтів КГ-2 достовірно частіше $(\mathrm{p}<0,001)$ зустрічається підвищення даного показника вище вказаної норми, ніж серед осіб КГ-1 (у $(96,2 \pm 2,6) \%$ та $(61,9 \pm 10,6) \%$ осіб 
відповідно). Це визначило високу діагностичну цінність даного показника на рівні ( $\mathrm{I}=2,052$ біт) та силу впливу $\left(\mathrm{n}^{2}=19,0 \%\right)$. На третьому ранговому місці - маркер хронічного запалення - TNF- $\alpha$. Підвищення його концентрації у крові вище встановленої норми обумовило високу інформативну цінність даного показника ( $\mathrm{I}=1,897$ біт) та силу впливу $\left(\mathrm{\eta}^{2}=16,0 \%\right)$. Діагностично значиме підвищення концентрації гормону жирової тканини - лептину майже у 2 рази більше серед пацієнтів з високим ССР у порівнянні з КГ-1: $(81,1 \pm 5,4) \%$ та $(38,1 \pm 10,6) \%(\mathrm{p}<0,001)$ осіб відповідно, обумовило четверте рангове місце серед розглянутих факторів, високу інформативну цінність на рівні I = 1,817 біт, та силу впливу $\left(\mathrm{n}^{2}=16,0 \%\right)$. Підвищення рівня ІА вище встановленої норми зустрічається серед $(84,9 \pm 4,9) \%$ пацієнтів КГ-2 та $(52,4 \pm 10,9) \%$ - осіб КГ-1 (p<0,003), що визначило його п'яте рангове місце серед досліджених критеріїв підвищеного ССР, високу інформативну цінність на рівні $\mathrm{I}=1,153$ біт, та силу впливу $\left(\mathrm{\eta}^{2}=10,0 \%\right)$. Шосте рангове місце займає показник стану ендотелію - ЕДВЗ. Зменшення даного показника менше $10 \%$ відмічається серед $(54,7 \pm 6,8) \%$ осіб КГ-2 - із помірним та високим ССР, та у майже в двічі меншої кількості $(23,8 \pm 9,3) \%$ пацієнтів порівнюваної КГ-1 $(\mathrm{p}<0,016)$ відповідно, що обумовило високу діагностичну цінність даного показника ( $\mathrm{I}=0,907$ біт), а також силу впливу на рівні $\eta^{2}=7,0 \%$. Збільшення індексу маси тіла (IMT) вище показника 35,0 достовірно частіше відмічалося серед пацієнтів КГ-2 - $(32,1 \pm 6,4) \%$ у порівнянні з пацієнтами КГ-1 $(14,3 \pm 7,6) \%(\mathrm{p}<0,010)$, що визначило сьоме рангове місце серед діагностичних критеріїв високого ССР, високу інформативну цінність на рівні I $=0,424$ біт, та силу впливу $\left(\eta^{2}=1,0 \%\right)$.

Таблиця 2. Діагностична інформативність та прогностичне значення клінікоанамнестичних, лабораторних та інструментальних показників стосовно рівня серцевосудинного ризику

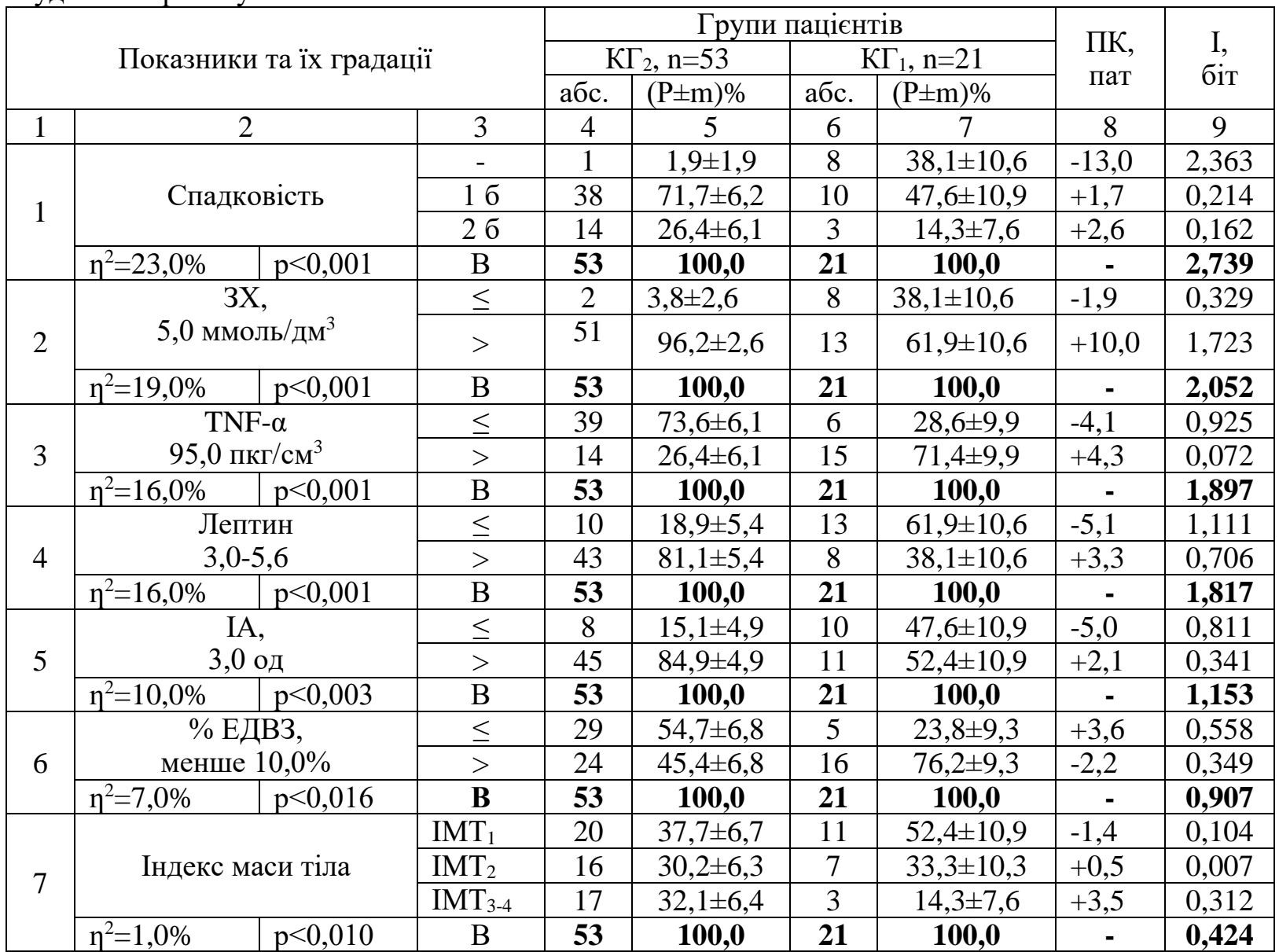

Примітка 1. В - всього.

Примітка 2. ПК - прогностичний коефіцієнт (пат).

Примітка $3 . \eta^{2}$ - сила впливу фактора на розбіжність груп (\%).

Примітка 4. I - інформативність (біт).

Примітка 5. абс. - наповнюваність груп та підгруп порівняння (осіб). 
Таким чином, визначені критерії високого ССР, що включені до таблиці прогнозування, розміщені достовірні $(\mathrm{p}<0,010)$ та високоінформативні ( $\mathrm{I} \geq 0,700$ біт).

Висновки. Таким чином, за результатами проведеного дослідження встановлено:

1. Діагностично значимим є розрахунок відносного ССР серед осіб молодого віку із АГ I ступеня та надмірною масою тіла для вибору подальшої тактики ведення даної когорти пацієнтів.

2. Найбільш поширеним фактором ризику СС3 є недотримання здорового способу харчування, а саме вживання в раціоні великої кількості кухонної солі та тваринних жирів. Відмічено, що даний фактор достовірно частіше (на рівні $\mathrm{p}<0,05$ ) виявляється серед осіб чоловічої статі, як у загальному, так і у групах порівняння.

3. Високу достовірну значимість та інформативність на рівні $\mathrm{I} \geq 0,700$ біт в інтерпритації серцево-судинного ризику мають наступні критерії: обтяжений спадковий анамнез за ранніми серцево-судинними захворюваннями, підвищення рівня 3X, маркеру хронічного запалення TNF- $\alpha$, гормону жирової клітковини - лептину, індексу атерогенності, стан функції ендотелії за показником ЕДВЗ та індекс маси тіла.

\section{ЛIТЕРАТУРА}

1. Свропейська база медико - статистичної інформації. URL: http://medstat.gov.ua/ukr/publications.html.

2. Luscher, T.F. (2018). Epidemiology of cardiovascular disease: the new ESC Atlas and beyond. European Heart Journal,39(7), 489-492.

3. Ferket, B.S., van Kempen, B.J., Hunink, M.G. (2014). Predictive value of updating Framingham risk scores with novel risk markers in the U.S. General population. PLoS One, 9 (2), 88-312.

4. Findings from the Global Burden of Disease Study 2017. (2018). Institute for Health Metrics and Evaluation. The Lancet, 27.

5. Гриневич, В.Б., Сас, Е. И., Кравчук, Ю.А. (2012). Абдоминальное ожирение: клинико-социальные аспекты проблемы. Ожирение и метаболизм, (2), 28-32.

6. 2016 European Guidelines on cardiovascular disease prevention in clinical practice. (2016). European Heart Journal, 0 (37), 2315-2381.

7. Williams, B., Mancia, G., Spiering, W. (2018). 2018 ESC/ESH Guidelines for the management of arterial hypertension. Journal of Hypertension, 36, 1953-2041.

8. Алексеев, В.В., Карпищенко, А.И. (2012). Медицинские лабораторные технологии: руководство по клинической лабораторной диагностике: в 2 т. Москва: ГЭОТАР-Медиа. Т. 1. 472.

9. World Medical Declaration of Helsinki. Ethical Principles for Medical Research Involving Human Subjects. (2004). WMA. 32.

10. Guidance for Industry: E6 Good Clinical Practice: Consolidated Guidance. (1996). 58.

11. Заклади охорони здоров'я та захворюваність населення України у 2017році. (2018). Державна служба статистики України. Статистичний збірник. Київ. http://www.ukrstat.gov.ua/druk/publicat/kat_u/2018/zb/06/zb_zoz_17.pdf.

12. Гублер, Е.В. (1978) Вычеслительные методы анализа и распознавания патологических процессов. Львов: Медицина. 294.

13. Гублер, Е.В. (1992). Клиническая патоинформатика в педиатрии. Ленинград: Медицина. 211. 